\title{
Diagnostic Value of the Leaf Chlorophyll in Some Members of the Family Euphorbiaceae Juss
}

\author{
Adewumi Aderiike Grace ${ }^{1, ~ *, ~ A b d u l r a h a m a n ~ A b d u l l a h i ~ A l a n a m u ², ~ O l a d e l e ~ F e l i x ~ A y o t u n d e ², ~}$ \\ Idika Digbo Iku", Ogunnowo Ayodele Adewole ${ }^{1}$
}

${ }^{1}$ Department of Basic Sciences, Babcock University, Ilishan Remo, Nigeria

${ }^{2}$ Department of Plant Biology, University of Ilorin, Ilorin, Nigeria

Email address:

adewumiga@gmail.com (A. A. Grace)

${ }^{*}$ Corresponding author

\section{To cite this article:}

Adewumi Aderiike Grace, Abdulrahaman Abdullahi Alanamu, Oladele Felix Ayotunde, Idika Digbo Iku, Ogunnowo Ayodele Adewole. Diagnostic Value of the Leaf Chlorophyll in Some Members of the Family Euphorbiaceae Juss. American Journal of Biological and Environmental Statistics. Vol. 5, No. 2, 2019, pp. 16-20. doi: 10.11648/j.ajbes.20190502.11

Received: April 23, 2019; Accepted: May 31, 2019; Published: July 1, 2019

\begin{abstract}
The spurge family Euphorbiaceae Juss. is a large family of flowering plants, most are herbs, but some, especially in the tropics, are also shrubs or trees, succulent and resemble cacti. Diagnostic values of the leaf chlorophyll of seven members of two genera (Euphorbia L. and Jatropha L.) of Euphorbiaceae Juss. were studied namely E. neriifolia, E. heterophylla, E. convolvuloides, E. hirta, J. curcas, J. gossypifolia and J. multifida. Analysis of variance was used to test for significance differences among the seven taxa considered. There is correlation between the chlorophyll content and leaf area; the plant (E. heterophylla) with larger leaf area $\left(203.49 \mathrm{~cm}^{2}\right)$ has highest chlorophyll content $\left(8.63 \mathrm{~g} / \mathrm{cm}^{2}\right)$ and $J$. curcashas the lowest mean leaf area $\left(64.41 \mathrm{~cm}^{2}\right)$ lowest chlorophyll content of $1.28 \mathrm{~g} / \mathrm{cm}^{2}$. Such correlation was not observed between the leaf per gram fresh weight and chlorophyll contentand \% chlorophyll content, where E. convolvuloides has the higher leaf area per gram fresh weight $(162.79 \mathrm{~g})$ and E. heterophylla has the least $(89.85 \mathrm{~g})$. Generally, species of Euphorbia have higher features in \% chlorophyll content (E. heterophylla-75.07\%), chlorophyll content (E. heterophylla-8.63g/ $\mathrm{cm}^{2}$ ), leaf area per gram fresh weight (E. convolvuloides-162.79g) and leaf area (E. heterophylla-203.49) than the Jatropha species. These features are found to be good taxonomic characters and thus indented dichotomous taxonomic keyswere constructed based separately for the two genera.
\end{abstract}

Keywords: Chlorophyll, Diagnostic Value, Euphorbia, Jatropha, Leaf, Taxonomy

\section{Introduction}

The spurge family Euphorbiaceae Juss. is a large family of flowering plants with 300 genera and around 7, 500 species. Most are herbs, but some, especially in the tropics, are also shrubs or trees, succulent and resemble cacti $[1,2]$. This family occurs mainly in the tropics, with the majority of the species in the indo-Malayan and tropical America. There is a large variety in tropical Africa, but it is not as abundant or varied as in these two other tropical regions.

The leaves are alternate, seldom opposite, with stipules. They are mainly simple, but where compound, are always palmate, never pinnate [3]. Stipules may be reduced to hairs, glands, or spines, or in succulent species are sometimes absent. The radially symmetrical flowers are unisexual, with the male and the female flowers usually occurring on the same plant. As can be expected from such a large family, there is a wide variety in the structure of the flowers. They can be monoecious or dioecious. The stamens (the male organs) can number from one to 10 (or even more). The female flowers are hypogynous, that is, with superior ovaries $[4,5]$.

The genera in tribe Euphorbieae Dumort, subtribe Euphorbiinae Griseb. (Euphorbia L. and close relatives) show a highly specialized form of pseudanthium ("false flower" made up of several true flowers) called a cyathium. This is usually a small, cup-like involucre consisting of fused-together bracts and peripheral nectary glands, 
surrounding a ring of male flowers, each a single stamen. In the middle of the cyathium stands a female flower: a single pistil with branched stigmas. This whole arrangement resembles a single flower. The fruit is usually a schizocarp, but sometimes a drupe. A typical schizocarp is the regma, a capsular fruit with three or more cells, each of which splits open at maturity into separate parts and then breaks away explosively, scattering the small seeds. The family contains a large variety of phytotoxins (toxic substances produced by plants), mainly diterrpene esters, alkaloids, glycosides, and ricin-type toxins [4].

A milky latex is a characteristic of the subfamilies Euphorbioideae and Crotonoideae. This latex is poisonous in the Euphorbioideae, but innocuous in the Crotonoideae. The latex of spurge has been used as a laxative. Recent molecular studies have shown that the enigmatic family Rafflesiaceae Dum., which was only recently recognized to belong to order Malpighiales Juss. ex Bercht. \& Presl, is derived from within Euphorbiaceae [4].

A number of plants of the spurge family are of considerable economic importance. Prominent plants include cassava (Manihot esculenta Crantz), castor oil plant (Ricinus communis L.), Barbados nut (Jatropha curcasL.), and the Para rubber tree (Hevea brasiliensisMull. Arg.). Many are grown as ornamental plants, such as poinsettia (Euphorbia pulcherrimaWilld. ex. Klotzsch). Leafy spurge (Euphorbia esula) and Chinese tallow (Triadica sebifera (L.) Small) are invasive weeds in North America. In medicine, some species of Euphorbiaceae have proved effective against genital herpes [6]

Chemotaxonomy is the use of biochemistry in taxonomic studies of living things. Living organisms produce many types of natural products in varying amounts. The distribution of these products and their biosynthetic pathways correspond well with existing taxonomic arrangements based on more traditional criteria such as morphology. In some cases chemical data have contradicted existing hypotheses, which necessitates reexamination of the problem or, more positively, chemical data have provided decisive information in situations where other forms of data are insufficiently discriminatory.

In addition to the use of morphological characters like leaves and flowers, a large family such as Euphorbiaceae need to be further exploited taxonomically with the of some other characters like chemicals, protein bandings, pollen types and many more. In this work, chlorophyll content in seven species namely Euphobia neriifolia L., E. heterophylla L., E. convolvuloides Hochst. ex Benth., E. hirta L., Jatropha curcas L., J. gossypifolia L. and J. multifida L. was used to delimit them. Chlorophyll is a term used for several closely related green pigments found in photosynthetic organisms. Chlorophyll is an essential element to the plants during photosynthesis and is an important substance that can be used as nutritional approaches in decreasing blood sugar, in detoxification, in digestion, excretion and lowering the allergens. Chlorophyll is one of the antioxidant compounds which are stored in the chloroplast of green leaf plants. Normally it has been found in the area of green leaves, stems, flowers and roots. Because of abundant of chlorophyll in the leaves, the leaves were studied for the chlorophyll content in the selected species [7-9].

The taxonomy of the family can, however, be enhanced by looking into possible use of non-morphological features such as chlorophyll density and chlorophyll content to identify and distinguish the species. Hence, this study elucidated the chlorophyll contents of the selected 8 species from the genera Euphorbia and Jatropha $L$. with 4 and 3 species from the former and latter respectively. Knowledge on the chlorophyll content of species of the Euphorbiaceae could be useful to identify candidates' species for multiplication and use for aesthetic and environmental purposes.

\section{Materials and Methods}

Leaves of seven species (4 species of Euphorbia and 3 species of Jatropha) of the family Euphorbiaceae used for chlorophyll content and density studies were collected in Ilorin, Oke Ode and Ila Orangun, all in Nigeria (Table 1). A sample size of 30 leaves was used for each of the experiments performed in the study.

Table 1. List of taxa of the genera Euphorbia and Jatropha.

\begin{tabular}{lll}
\hline Taxa & Common names & Place of collection \\
\hline Jatropha curcas L. & Purging nut, fig nut & S. D. A. Secondary School premises, Oke Ode \\
Jatropha gossypifolia L. & Red jatropha, bellyache bush & S. D. A. Secondary School premises, Oke Ode \\
Jatropha multifida L. & Physic nut, coral plant & S. D. A. Secondary School premises, Oke Ode \\
Euphorbia convolvuloides Hochst. ex Benth. & Spurge & Osun State College of Education, Ila Orangun \\
Euphorbia heterophylla L. & Spurge & University of Ilorin premises \\
Euphorbia hirta L. & Asthma weed, catshair & S. D. A. Secondary School premises, Oke Ode \\
Euphorbia neriifolia L. & Hedge Euphorbia, common milk hedge & Osun State College of Education, Ila Orangun \\
\hline
\end{tabular}

Each leaf specimen (of $1.25 \mathrm{~g}$ ) was weighed using a weighing balance. The area of the leaf specimen was measured using graph sheet method. The weighed specimen $\left(\mathrm{X}_{\mathrm{o}}\right)$ was cut into pieces and boiled in $200 \mathrm{ml}$ of fresh ethanol for $20 \mathrm{~min}$. after boiling. Boiled specimen was taken out and allowed to dry i.e. the ethanol was allowed to evaporate. After evaporation the specimen was then reweighed $\left(\mathrm{X}_{1}\right)$ and then the new weight was recorded. The difference between the old weight $\left(\mathrm{X}_{\mathrm{o}}\right)$ and new $\left(\mathrm{X}_{1}\right)$ is the weight of the chlorophyll i.e. $\mathrm{X}_{\mathrm{o}}-\mathrm{X}_{1}=\mathrm{Xg}$ (weight of chlorophyll).

Chlorophyll content was obtained by dividing weight of chlorophyll by the leaf area and multiplied by 100 i.e. $\left(\mathrm{x} / \mathrm{x}_{0}\right)$ $100 \mathrm{~g}$.

The chlorophyll density $\left(\mathrm{g} / \mathrm{cm}^{2}\right)$ was obtained by dividing the chlorophyll weight by its leaf area.

The leaf area per gram fresh weight was determined by 
dividing the leaf area with its initial weight. The sample size used was 30. Data collected were subjected to statistical analysis namely: analysis of variance and Duncan's multiple range test [10-12].

Indented dichotomous key was constructed for the seven taxa (separately for the 2 genera of Euphorbia and Jatropha) in Euphorbiaceae family based on chlorophyll parameters (chlorophyll content and percentage chlorophyll content) studied.

\section{Results and Discussion}

Many characters are designated as taxonomic characters i.e. they are good features in delimiting plant taxa at specific, generic and family levels. Some of these characters are leaves, fruits, stomata, trichomes, chromosome behaviours (e.g. numbers, length, position of centromere etc), and chemicals [13-16]. Meanwhile, the use of chlorophyll in taxonomy is very rear. Some of scanty incidences are those published by a study [17]. Chlorophyll content is not leaf area and leaf area per gram fresh weight dependent among the seven taxa except in E. heterophylla and J. curcas which possessed the largest and smallest leaf area and highest and lowest chlorophyll content respectively. Euphorbia heterophyllaand E. convolvuloideshas the largest mean leaf area of $203.49 \mathrm{~cm}^{2}$ and leaf area per gram fresh weight of $162.79 \mathrm{~cm}^{2}$ respectively produced the lowest \% chlorophyll content and chlorophyll density of $28.16 \%$ and $1.75 \times 10^{-2}$ respectively. Meanwhile, $J$. curcas that has smallest leaf area of $64.41 \mathrm{~cm}^{2}$ and leaf area per gram fresh weight of $52.33 \mathrm{~cm}^{2}$, it produced $\%$ chlorophyll content and least chlorophyll density of $66.88 \%$ and $1.28 \times 10^{-2}$ respectively (Tables 2 and 3). One of the implications of this is that plants with small leaf area have closely parked chlorophyll (high chlorophyll density) than some others with large leaves. Thus, they can help to remove the carbon dioxide for photosynthetic purpose.

Table 2. Leaf area $\left(\mathrm{cm}^{2}\right)$ and leaf area per gram fresh weight of some taxa in the family Euphorbiaceae.

\begin{tabular}{|c|c|c|c|c|c|c|}
\hline \multirow{2}{*}{ Taxa } & \multicolumn{3}{|l|}{ Leaf area $\left(\mathrm{cm}^{2}\right)$} & \multicolumn{3}{|c|}{ Leaf area per gram fresh weight } \\
\hline & Mean \pm SD & Minimum & Maximum & Mean \pm SD & Minimum & Maximum \\
\hline Jatropha multifida & $167.09 \pm 21.73^{b}$ & 75.80 & 187.59 & $133.67 \pm 17.39^{c}$ & 60.64 & 150.07 \\
\hline Jatropha curcas & $64.41 \pm 6.27^{\mathrm{e}}$ & 54.60 & 79.66 & $52.33 \pm 5.01^{\mathrm{e}}$ & 43.68 & 59.73 \\
\hline Jatropha gossypifolia & $175.54 \pm 23.45^{\mathrm{b}}$ & 100.21 & 199.00 & $125.71 \pm 18.78^{\mathrm{c}}$ & 80.16 & 159.20 \\
\hline Euphorbia hirta & $142.55 \pm 5.99^{c}$ & 135.20 & 153.01 & $144.04 \pm 4.79^{\mathrm{ab}}$ & 108.16 & 122.41 \\
\hline Euphorbia heterophylla & $112.32 \pm 17.47^{\mathrm{d}}$ & 85.32 & 148.3 & $89.85 \pm 13.97^{\mathrm{d}}$ & 68.26 & 118.65 \\
\hline Euphorbia convolvuloides & $203.49 \pm 24.97^{\mathrm{a}}$ & 159.11 & 241.52 & $162.79 \pm 19.99^{\mathrm{a}}$ & 127.29 & 193.21 \\
\hline
\end{tabular}

Mean with the same letters along the column are not significantly different.

Table 3. Percentage chlorophyll content in the leaves of some taxa in the family Euphorbiaceae.

\begin{tabular}{|c|c|c|c|c|c|c|}
\hline \multirow{2}{*}{ Taxa } & \multicolumn{3}{|c|}{ \% chlorophyll content } & \multicolumn{3}{|c|}{ Chlorophyll content $\left(\mathrm{g} / \mathrm{cm}^{2}\right)$} \\
\hline & Mean \pm SD & Minimum & Maximum & Mean \pm SD & Minimum & Maximum \\
\hline Jatropha multifida & $42.13 \pm 11.25^{\mathrm{d}}$ & 28.00 & 60.00 & $3.23 \pm 10^{-3} \pm 1.13 \times 10^{-3 b}$ & 0.0019 & 0.0073 \\
\hline Jatropha curcas & $66.88 \pm 3.51^{\mathrm{b}}$ & 60.00 & 70.00 & $1.28 \times 10^{-2} \pm 1.32 \times 10^{-3 \mathrm{a}}$ & 0.0103 & 0.0156 \\
\hline Jatropha gossypifolia & $61.84 \pm 3.74^{\mathrm{bc}}$ & 56.00 & 70.40 & $5.07 \times 10^{-3} \pm 1.072 \times 10^{-3 b}$ & 0.0038 & 0.0076 \\
\hline Euphorbia hirta & $39.92 \pm 5.49^{\mathrm{d}}$ & 34.40 & 64.00 & $3.51 \times 10^{-3} \pm 5.39 \times 10^{-4 c}$ & 0.0030 & 0.0059 \\
\hline Euphorbia heterophylla & $75.07 \pm 11.14^{\mathrm{a}}$ & 52.00 & 88.80 & $8.63 \times 10^{-3} \pm 2.17 \times 10^{-3 b}$ & 0.0051 & 0.0123 \\
\hline Euphorbia convolvuloides & $28.16 \pm 8.28^{\mathrm{e}}$ & 20.00 & 40.00 & $1.75 \times 10^{-3} \pm 5.53 \times 10^{-4 c}$ & 0.0011 & 0.0033 \\
\hline
\end{tabular}

Mean with the same letters along the column are not significantly different.

Data obtained from the leaf area, \% chlorophyll content, chlorophyll density and leaf area per gram fresh weight showed that there are some levels of variations among the studied species. For instance, based on leaf area, \% chlorophyll content, chlorophyll density and leaf area per gram fresh weight, J. curcas and E. convolvuloides, E. convolvuloides and E. heterophylla, J. curcas, and J. curcas and E. convolvuloides differed significantly from other species respectively. Meanwhile, J. multifida, J. gossypifolia and E. neriifolia; and E. hirta and E. neriifolia are not significantly different in leaf area. Jatropha curcas and $J$. gossypifolia, E. neriifolia and J. gossypifolia are not differed in the amount of the \% chlorophyll content. In term of chlorophyll density, J. multifida, J. gossypifolia and E. heterophylla, and E. hirta, E. neriifolia and E. convolvuloides are not significantly different. Jatropha multifida, J. gossypifolia and E. neriifolia, and $E$. hirta and $E$. convolvuloides have the same fresh weight of leaf area per gram.

Chlorophyll which play a vital role in the photosynthetic process during which carbondioxide (one of the greenhouse gases) is absorbed into the plant leaves is an essential material. Greenhouse effect is the accumulation of toxic green house gases in the atmosphere, which lead to global warming. Global warming is the gradual warming of the internal temperature of the earth $[18,19]$. Some of the green house gases along with $\mathrm{CO}_{2}$ include methane, water vapour etc. The accumulation of such gases and many more, lead to global warming which has 
effect on climate $[20,21]$. Therefore, a plant with high chlorophyll content will go a long way in mitigating against the greenhouse gases. The results obtained from this study revealed that six out of all the seven taxa studied namely $E$. neriifolia, E. heterophylla, E. convolvuloides, E. hirta, J. gossypifolia and J. multifida are possible good specimens for multiplication and cultivation to help reduce the accumulation of carbon dioxide in the atmosphere.

From the data generated from this work on the leaf area, \% chlorophyll content, chlorophyll density and leaf area per gram fresh weight, which showed variations and similarities between the seven species within genus and between the genera. The characters are said to be good taxonomic characters. Therefore, the following indented dichotomous key to taxa in genera Euphorbia and Jatropha of family Euphorbiaceae were constructed separately.

a For four species of Euphorbia:

1a Chlorophyll content (\%), 2

2a Leaf area $\left(\mathrm{cm}^{2}\right)$

$28.16-39.92$ chlorophyll density $\left(\mathrm{g} / \mathrm{cm}^{2}\right) \quad 3.51 \times 10^{-3}$ Leaf area for gram fresh weight 144.04 E. hirta

2b Leaf area $\left(\mathrm{cm}^{2}\right)$ chlorophyll density $\left(\mathrm{g} / \mathrm{cm}^{2}\right)$ Leaf area per gram fresh weight E. heterophylla

3a Leaf area $\left(\mathrm{cm}^{2}\right)$ chlorophyll density $\left(\mathrm{g} / \mathrm{cm}^{2}\right)$ leaf area per gram fresh weight E. neriifolia

$3 b \quad$ Leaf area $\left(\mathrm{cm}^{2}\right)$ chlorophyll density $\left(\mathrm{g} / \mathrm{cm}^{2}\right)$ leaf area per gram fresh weight E. convolvuloides

b For three species of Jatropha:

1a Chlorophyll content (\%) 2

2a Leaf area $\left(\mathrm{cm}^{2}\right)$ chlorophyll density $\left(\mathrm{g} / \mathrm{cm}^{2}\right)$ leaf area per gram fresh weight J. gossypifolia

2b Leaf area $\left(\mathrm{cm}^{2}\right)$ chlorophyll density $\left(\mathrm{g} / \mathrm{cm}^{2}\right)$ leaf area per gram fresh weight J. Curcas

1b Chlorophyll content (\%) leaf area $\left(\mathrm{cm}^{2}\right)$ chlorophyll density $\left(\mathrm{g} / \mathrm{cm}^{2}\right)$ leaf area per gram fresh weight J. multifida

\section{Conclusion}

The results obtained from this study revealed that six out of all the seven taxa studied namelyE. neriifolia, $E$.
175.54

$5.07 \times 10^{-3}$

125.71

64.41

$1.28 \times 10^{-3}$

52.33

42.13

167.09

$3.23 \times 10^{-3}$

133.67 heterophylla, E. convolvuloides, E. hirta, J. gossypifolia and $J$. multifida are possible good specimens for multiplication and cultivation to help reduce the accumulation of carbon dioxide in the atmosphere. Hence, leaf chlorophyll content can be used as good taxonomic characters.

\section{References}

[1] Davis, C. C., Latvis, M., Nickrent, D. L., Wurdack, K. J., and Baum, D. A. (2007). Floral gigantism in Rafflesiaceae Science Express Published online. Pp 618-729.

[2] Natasha Nguyen (2014). "Convergent evolution of cacti and euphorbias". Retrieved 31 March 2007.

[3] Sagun, V. G., Levin, G. A., and Van-welzen, P. C. (2010). Blumea. 55: 21-66.

[4] Charle, C. D., L. Maribeth, L. W. Daniel, J. W. Kenneth and A. B. David 2007. Floral gigantism in Rafflesiaceae. Science Express Publishers. http://www.wikipedia.org. Publish online January 11, 2007.

[5] De-Paula, O. C., Sajo, M. G., Prenner, G., Cordeiro, I. \& Rudall, P. J. (2011) Morphology, development and homologies of the perianth and floral nectaries in Croton and Astrae (Euphorbiaceae-Malpighiales). Plant Systematics and Evolution 292: 1-14.

[6] Kumar S, Malhotra R, Kumar D. 2017. Euphorbia hirta: Its chemistry, traditional and medicinal uses, and pharmacological activities. 4: 58-61. doi: 10.4103/0973.

[7] Kolade, T. 2008. Seminar at the Kwara State Ministry of Agriculture, Ilorin, on Renewable Energy Resources.

[8] Mechl, G. A. 2005. How much more global warming and sea level rise. Science 37: 169-172.

[9] Sevik H., Karakas H., Senoz E. 2013 Evaluation of air quality in terms of the amount of carbon dioxide in black sea region. International Journal of Engineering Science \& Research Technology. 2 (2), 805.

[10] Bailey, N. T. J. 1995. Statistical Method in Biology. Cambridge University Press, Cambridge, P. 225.

[11] Wackerly DD, Mendenhall W III, Scheaffer RL. 2002. Mathematical Statistics with Applications. 6th ed. Pacific Grove, CA: Druxbury Press.

[12] Duncan, D. B. 1995. Multiple Ranges and Multiple t-tables. Biometric, 11: 1-42.

[13] Abubakar, B. Y. and A. L. Yunusa. 1998. Epidermal structure and stomatal ontogeny as an aid to the taxonomic identification of some species of Acacia (Leguminosae Mimosoideae) from nigeria. Nigerian Journal of Botany 11: 117-123.

[14] AbdulRahaman, A. A. and F. A. Oladele. 2005. Stomata, trichomes and epidermal cells as diagnostic features in six species of the genus Ocimum L. (Lamiaceae). Nigerian Journal of Botany 18: 214-223.

[15] Kadri, A. B., D. Utubor and O. T. Ogundipe. 2013. Taxonomic relationships in Lagenaria seringe (Cucurbitaceae) based on foliar epidermal morphology. Thaiszia-Journal of Botany, Kosice 23: 47-59. 
[16] Ranjbar, M. And Z. Nourallahi. 2016. Chromosome numbers and meiotic behaviour of the genus Paracaryum (Boraginaceae) from Iran. Webbia: Journal of Plant Taxonomy and Geography 61 (1): 83-90.

[17] Ajayan, K. V., R. L. Babu and B. PatilBayakka. 2015. Variability of stomatal index and chlorophyll content in four species of Solanaceae members. International Research Journal of Biological Sciences 4 (2): 16-20.

[18] Blois, J. L., Williams, J. W., Fitzpatrick, M. C., Jackson, S. T., and Ferrier, S. 2013: Space can substitute for time in predicting climate change effects on biodiversity, P. Natl. Acad. Sci. USA, 110, 9374-9379, doi: 10.1073 pnas. 1220228110 .
[19] Forster, J. and J. Piers. 2007. Changes in Atmospheric constitute and Radiative forcing. Climate Change, $7^{\text {th }}$ ed., NY: W. N Freeman and company publisher. pp. 188-193.

[20] Peason, P. N. and M. R. Palmer. 2008. Atmospheric carbon dioxides concentrations over the past 60 million years. American Journal of Bio-chemistry 406: 695-699.

[21] Harris, I., Jones, P. D., Osborn, T. J., and Lister, D. H 2013: Updated high-resolution grids of monthly climatic observations-the CRU TS3.10 Dataset, Int. J. Climatol., doi: 10.1002/joc.3711. 